\title{
Solubilization of particles in sediment traps: revising the stoichiometry of mixed layer export
}

\author{
A. N. Antia \\ Leibniz-Institut für Meereswissenschaften, Res. Div. Marine Biogeochemistry, Düsternbrooker Weg 20, 24105 Kiel, Germany \\ Received: 28 February 2005 - Published in Biogeosciences Discussions: 5 April 2005 \\ Revised: 16 June 2005 - Accepted: 13 July 2005 - Published: 4 August 2005
}

\begin{abstract}
Sinking particles, once caught in sediment trap jars, release dissolved elements into the surrounding medium through leaching from their pore fluids, chemical dissolution and the activity of free exoenzymes. This results in an increase in dissolved elements in the trap jar supernatant. Elemental fluxes as traditionally measured by sediment traps underestimate total export when this particle-associated dissolved flux is not considered. The errors introduced are variable and alter both the absolute levels of flux as well as the stoichiometry of export. These errors have been quantified and corrections applied for samples from sediment traps in the North Atlantic based on measurements of excess dissolved carbon, nitrogen, phosphorus, silica and calcium in the supernatant of the collection cups. At the base of the winter mixed layer, on average $90 \pm 6 \%$ of phosphorus fluxes are found as excess phosphate whereas for carbon and nitrogen dissolved concentrations account for $30( \pm 8) \%$ and $47( \pm 11) \%$ of total fluxes respectively. Excess dissolved silica is on average $61( \pm 17) \%$ of total biogenic silica flux. Little $(<10 \%)$ of calcium is solubilized. The proportion of dissolved to total flux decreases with trap deployment depth. Calculations of the C:N:P ratios for particles only are well above the Redfield ratios of 106:16:1 (Redfield et al., 1963), although the mid-water dissolved N:P and N:Si values as well as the $\mathrm{C}: \mathrm{N}: \mathrm{P}$ ratios of remineralisation along isopycnals conform to the Redfield ratios at this site. Accounting for dissolved fluxes of all these elements brings the stoichiometry of export in agreement with the Redfield Ratio and with other geochemical estimates of winter mixed layer export. A factor of 3 to 4 higher ratios of organic: inorganic carbon export also implies that the net atmospheric $\mathrm{CO}_{2}$ sequestration by the biological pump is about $50 \%$ higher at this site when the dissolved elemental fluxes are considered. Solubilization is thus a process that should be accounted for in protocols used to measure vertical fluxes with sediment traps.
\end{abstract}

Correspondence to: A. N. Antia

(aantia@ifm-geomar.de)

\section{Introduction}

The biogenic production of particles in the surface ocean leads to incorporation of major and minor elements into organic material or on matrices that, after coagulation and aggregation sink out of the upper mixed layer and transport these elements to the deep sea and sea floor. The proportion in which these elements leave the surface mixed layer determines their relative residence times at the surface and their deep-water stoichiometry. Since Redfield et al. (1963) pointed out the relative constancy of the ratios of carbon, nitrogen and phosphorus ( $\mathrm{C}, \mathrm{N}$ and $\mathrm{P}$ ) in organic matter and dissolved inorganic N:P in the deep sea, this concept has been widely used to estimate fluxes of one element based on those of the others (e.g. MacCready and Quay, 2001). Indeed, this ratio is so accepted as being the "norm" that deviations in the so-called "Redfield ratios" of particles in surface waters are interpreted as "overproduction" of carbon, or an elevated efficiency of the biological pump (Körtzinger et al., 2001a; Engel et al., 2002). In the mesopelagial, changes in these ratios in sinking particles with depth are taken to reflect the remineralisation time and length scales of different elements (Honjo et al., 1982; Honjo and Manganini, 1993). Among the other bio-active elements, silicon (specifically the $\mathrm{N}: \mathrm{Si}$ ratio in upwelled water) determines the contribution of diatoms to new production, thus influencing species succession in a way that is important for particle export. Additionally, the ratio of inorganic carbon (primarily calcium carbonate) to organic carbon in particles exported from the winter mixed layer determines the efficiency of net atmospheric $\mathrm{CO}_{2}$ sequestration (Antia et al., 2001). Both silica and carbonates are thought to play a prominent role in ballasting material to accelerate its sinking speed (Armstrong et al., 2002; Klaas and Archer, 2002), so their contribution to sedimenting particles can potentially alter the efficiency of bulk export. For all these reasons, being able to accurately determine the fluxes of different elements and their ratios to each other is important in studies of ocean biogeochemistry.

(C) 2005 Author(s). This work is licensed under a Creative Commons License. 
Sediment traps, more correctly called particle interceptor traps, have been used for several decades to quantify and characterize the flux of elements from the surface to the deep sea. Despite uncertainties in the efficiency with which traps collect the true settling flux, they are still the sole means by which time-series sampling of sinking particles is done in the mid-ocean. Valuable insights into the close coupling of surface processes with mesopelagic and benthic fluxes as well as novel information on the vertical fluxes of major and minor elements has emerged from trap studies, contributing to our understanding of ocean biogeochemical cycles. Almost simultaneous with the enthusiasm in deploying traps in numerous environments came the sobering realization that they fell short of collecting the "true" sinking flux (e.g. Gardner, 1980, 2000; Buesseler, 1991; Gust et al., 1992, 1996). Of the many issues addressed, hydrodynamic biases (resulting from current speeds, trap tilt and trap geometry) appear to be a major problem, causing under- or over-collection of particles and sorting of particles based on size or other properties (Gust et al., 1996). In practice, though, the general acceptance was that once particles were caught, they could be well measured using conventional protocols for particulate analyses. Although the possible errors due to particle solubilization were pointed out early on (for example by the US GOFS Working Group on Sediment Trap Technology and Sampling; Knauer and Asper, 1989), this practice has persisted, largely due to a paucity of information quantifying the potential problem, and the differing deployment configurations and sites where traps are used.

A number of studies have reported solubilization/degradation of organic carbon (Gardner et al., 1983; Noji et al., 1999; Honjo et al., 1995), and nitrogen (Hansell and Newton, 1994; Kähler and Bauerfeind, 2001) amino acids (Lee and Cronin, 1984; Lee et al., 1992), fatty acids (Körtzinger et al., 1994), phosphate (Knauer et al., 1984; von Bodungen et al., 1991), dissolved inorganic nitrogen (primarily ammonium, Knauer et al., 1990; von Bodungen et al., 1991), silica (von Bodungen et al., 1991; Bauerfeind et al., 1997; Antia et al., 1999), metals (Knauer et al., 1984; Pohl et al., 2004) and particulate barium (Dymond and Collier, 1996). Despite finding that solubilization can account for a substantial proportion of the measured particulate flux, to date there has been no systematic analysis of the corrections that may need to be applied to arrive at values of the entire flux arriving in the trap. As important as errors in the absolute levels of flux are changes in the ratios of the elements to each other, as mentioned above.

When compiling existing data from the literature on dissolved compounds in trap supernatant, it became apparent that while some studies had looked at individual compounds no comprehensive data existed in which the major elements were measured for a single set of samples. The aim of this study is thus to measure the degree of solubilization of major elements (carbon, nitrogen, phosphorus, silica and calcium) from particles captured by sediment traps at different depths from long-term moorings in the North Atlantic and assess how this process affects the measurement of the stoichiometry of export.

\section{Materials and methods}

Conical, $0.5 \mathrm{~m}^{2}$ aperture Kiel-type sediment traps were deployed on 3 moorings at the European continental margin at depths between $600 \mathrm{~m}$ and $4000 \mathrm{~m}$. Details of mooring deployment and sample processing are given in Antia et al. (1999). Sedimentation rates of particulate organic carbon and nitrogen (POC and PON) and particulate biogenic silica (PSi) presented here are available from the OMEX database (http://www.bodc.ac.uk/projects/omex.html). Particulate organic phosphorus (POP) was measured after filtration, oxidation and colorimetric determination after Grasshoff et al. (1999).

Seawater from ca. $1000 \mathrm{~m}$ depth at the mooring sites, with borax-buffered mercuric chloride (final concentration $0.14 \%$ ) added as a poison, was used to fill the trap jars prior to deployment. Dissolved carbon, nitrogen, phosphorus and silicate were measured in this water and these values were used as background concentrations. After recovery and transport to the laboratory, sample cups were placed upright and particles allowed to settle to the bottom of the cups before further analyses. Supernatant water from above the particle pellet was carefully pipetted out, filtered through sterile $0.45 \mu \mathrm{m}$ polycarbonate filters and stored at $4^{\circ} \mathrm{C}$ in the dark. Samples were processed in the order in which they were exposed in the traps so that, including time of deployment and time between recovery and processing, all samples had been in the poisoned jars for at least 5 months and up to 1 year before analysis.

The supernatent was analyzed for the following variables: nitrate, nitrite, ammonium, silicate and phosphate, dissolved organic carbon (DOC) and nitrogen (DON) and dissolved calcium. $\mathrm{NO}_{2}, \mathrm{NO}_{3}, \mathrm{NH}_{4}, \mathrm{PO}_{4}, \mathrm{SiO}_{4}$ were analyzed using the manual methods described in Grasshoff et al. (1999). Samples were diluted 1:10 before nitrate analyses to keep the level of mercuric chloride below $0.02 \%$, so as not to compromise the efficiency of the cadmium reductor. DOC and DON were analyzed using the high temperature catalytic oxidation (HTCO) method and dissolved calcium using Inductively Coupled Plasma Atomic Emission Spectrometer (ICP AES) analyses. Dissolved organic phosphorus was measured in 119 samples as the increase in phosphate concentration after treatment with a strong oxidizing agent (Oxisolv, Merck).

The excess dissolved concentration of each element in supernatant was calculated as the difference between the measured value and the background value in water used to fill the sample cups. Total fluxes were calculated from the sum of dissolved and particulate fluxes of each element. In several cases and in particular for phosphorus, mean fluxes showed large variations due to extreme outliers in the data. These 


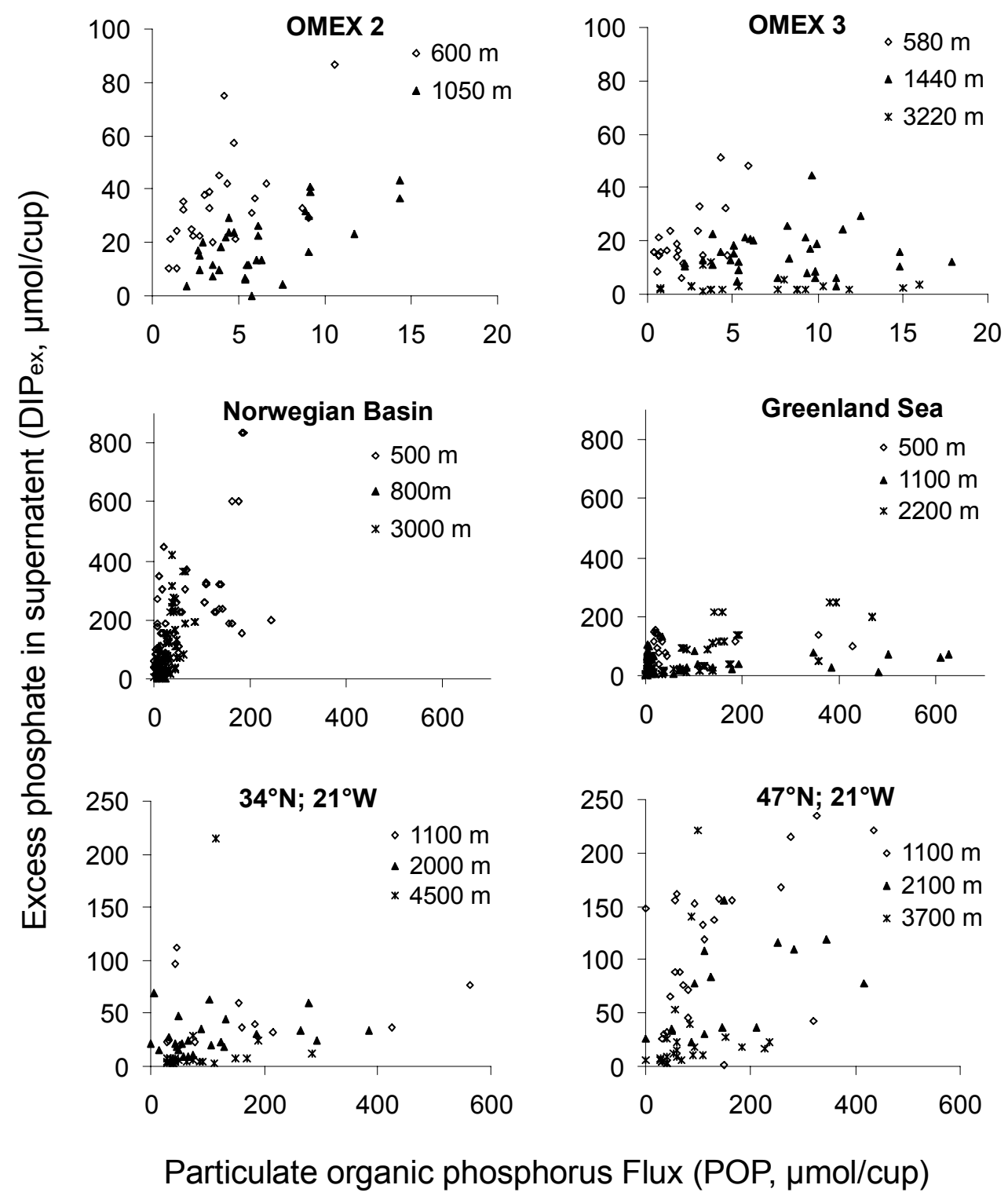

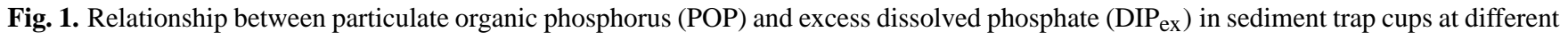
sites and depths as listed in Table 1.

were defined as values lying outside of three standard deviations from the mean and discarded from calculations. Generally 0,1 or 2 outliers per set of $21-40$ values were identified and eliminated.

Measurements done on the OMEX traps are compared to literature values taken from trap deployments in other environments. Data from the Greenland and Norwegian Seas were provided by the Special Research Project (313) of the University of Kiel and are available under http://www.ifm. uni-kiel.de/jgofs/dm/. Data from traps in the Southern Ocean are reported in Trull et al. (2001) and were obtained from Bray et al. (2000). The sources of other data are given in the caption of Table 1 .

\section{Results}

\subsection{Excess phosphorus in supernatant}

For all elements examined, moderate to substantial excess dissolved concentrations in supernatent were found. This was most pronounced for phosphorus, with a mean of $90 \pm 6.4 \%$ of the total phosphorus in trap jars found as excess phosphate $\left(\mathrm{DIP}_{\mathrm{ex}}\right)$ in supernatent at $600 \mathrm{~m}$ at the OMEX 3 site (Fig. 1a, Table 1). Excess dissolved organic phosphorus could not be detected, with a mean measured concentration of $1.04 \pm 2.7 \mu \mathrm{M}$. With increasing trap depth the proportion of $\mathrm{DIP}_{\mathrm{ex}}$ to total phosphorus found in the cups 
Table 1. The percentage contribution of excess dissolved organic carbon $\left(\mathrm{DOC}_{e x}\right)$, dissolved organic- and inorganic nitrogen (DON $\mathrm{D}_{e x}$, $\left.\mathrm{DIN}_{e x}\right)$, dissolved inorganic phosphorus $\left(\mathrm{DIP}_{e x}\right)$, dissolved calcium $\left(\mathrm{DCa}_{e x}\right)$ and silicic acid $\left(\mathrm{DSi}_{e x}\right)$ to total (particulate + dissolved) carbon, nitrogen, phosphorus, calcium and silica fluxes (TC, TN, TP, TCa and TSi, respectively) in sediment traps below the winter mixed layer.

\begin{tabular}{|c|c|c|c|c|c|c|c|c|c|}
\hline Site & $\begin{array}{l}\text { Depth } \\
(\mathrm{m})\end{array}$ & $\begin{array}{c}\mathrm{DOC}_{e x} \\
(\% \mathrm{TC}) \\
\text { Mean } \pm \mathrm{SD}\end{array}$ & $\begin{array}{c}\mathrm{DON}_{e x} \\
(\% \mathrm{TN}) \\
\text { Mean } \pm \mathrm{SD}\end{array}$ & $\begin{array}{c}\mathrm{DIN}_{e x} \\
(\% \mathrm{TN}) \\
\text { Mean } \pm \text { SD }\end{array}$ & $\begin{array}{c}\mathrm{DIP}_{e x} \\
(\% \mathrm{TP}) \\
\text { Mean } \pm \mathrm{SD}\end{array}$ & $\begin{array}{c}\mathrm{DCa}_{e x} \\
(\% \mathrm{TCa}) \\
\text { Mean } \pm \mathrm{SD}\end{array}$ & $\begin{array}{c}\mathrm{DSi}_{e x} \\
(\% \mathrm{TSi}) \\
\operatorname{Mean} \pm \mathrm{SD}\end{array}$ & Brine & Poison \\
\hline 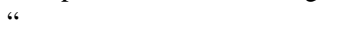 & 1100 & $28.3 \pm 9.0$ & $44.4 \pm 10.8$ & $3.9 \pm 1.1$ & $70.6 \pm 18.3$ & $7.5 \pm 5.3$ & $33.2 \pm 11.6$ & no & $\mathrm{HgCl}_{2}$ \\
\hline “ & 600 & $28.2 \pm 8.2$ & $45.4 \pm 45.4$ & $1.7 \pm 1.0$ & $90.4 \pm 6.4$ & $7.5 \pm 5.0$ & $60.9 \pm 7.4$ & no & $\mathrm{HgCl}_{2}$ \\
\hline “ & 1440 & $17.2 \pm 9.2$ & $29.4 \pm 9.8$ & $5.4 \pm 1.6$ & $61.6 \pm 20.4$ & $9.9 \pm 3.4$ & $35.9 \pm 16.5$ & no & $\mathrm{HgCl}_{2}$ \\
\hline $46.45^{\circ} \mathrm{S} ; 142.4^{\circ} \mathrm{E}^{2}$ & 1000 & & & & & & $24.5 \pm 10.1$ & yes & $\mathrm{HgCl}_{2}$ \\
\hline “ & 2000 & & & & & & $18.6 \pm 7.6$ & yes & $\mathrm{HgCl}_{2}$ \\
\hline “ & 3800 & & & & & & $23.8 \pm 9.4$ & yes & $\mathrm{HgCl}_{2}$ \\
\hline $51.0^{\circ} \mathrm{S} ; 141.44^{\circ} \mathrm{E}^{2}$ & 3300 & & & & & & $9.9 \pm 5.5$ & yes & $\mathrm{HgCl}_{2}$ \\
\hline $53.44^{\circ} \mathrm{S} ; 141.45^{\circ} \mathrm{E}^{2}$ & 800 & & & & & & $4.9 \pm 2.3$ & yes & $\mathrm{HgCl}_{2}$ \\
\hline $48^{\circ} \mathrm{N} ; 21^{\circ} \mathrm{W}^{3}$ & $1081 / 1202$ & & & & $51.1 \pm 15.1$ & & $10.2 \pm 4.4$ & no & Formalin \\
\hline " & $2018 / 2200$ & & & & $31.8 \pm 12.5$ & & $7.7 \pm 4.9$ & no & Formalin \\
\hline “ & $3718 / 3749$ & & & & $17.3 \pm 10.8$ & & $6.1 \pm 2.9$ & no & Formalin \\
\hline Norwegian Basin ${ }^{4}$ & 500 & & & & $79.6 \pm 13.6$ & & $34.9 \pm 21.1$ & no & $\mathrm{HgCl}_{2}$ \\
\hline “ & 800 & & & & $72.5 \pm 19.7$ & & $37.9 \pm 21.6$ & no & $\mathrm{HgCl}_{2}$ \\
\hline “ & 3000 & & & & $68.6 \pm 18.4$ & & $12.3 \pm 6.3$ & no & $\mathrm{HgCl}_{2}$ \\
\hline East Greenland Sea ${ }^{4}$ & 500 & & & & $78.4 \pm 16.5$ & & $35.0 \pm 17.7$ & no & $\mathrm{HgCl}_{2}$ \\
\hline “ & 1000 & & & & $64.7 \pm 36.1$ & & $35.7 \pm 18.7$ & no & $\mathrm{HgCl}_{2}$ \\
\hline “ & 2200 & & & & $39.7 \pm 23.0$ & & $22.9 \pm 15.0$ & no & $\mathrm{HgCl}_{2}$ \\
\hline “ & 500 & & & & & & & no & $\mathrm{HgCl}_{2}$ \\
\hline “ & 1000 & & & & & & & no & $\mathrm{HgCl}_{2}$ \\
\hline “ & 3495 & & & & $50 \pm 13$ & & & n.g. & $\mathrm{NaN}_{3}$ \\
\hline “ & 700 & & & & $70 \pm 8$ & & & n.g. & $\mathrm{NaN}_{3}$ \\
\hline “ & 1600 & & & & $49 \pm 16$ & & & n.g. & $\mathrm{NaN}_{3}$ \\
\hline “" & 3000 & & & & $26 \pm 10$ & & & n.g. & $\mathrm{NaN}_{3}$ \\
\hline Greenland Basin ${ }^{7}$ & $180 / 275$ & 33 & & & & & & no & $\mathrm{HgCl}_{2}$ \\
\hline “ & $775 / 900$ & 50 & & & & & & no & $\mathrm{HgCl}_{2}$ \\
\hline “ & $1735 / 2100$ & 63 & & & & & & no & $\mathrm{HgCl}_{2}$ \\
\hline Greenland Sea ${ }^{8}$ & 500 & & & $7.8-38$ & $94-98$ & & $45-55$ & no & $\mathrm{HgCl}_{2}$ \\
\hline
\end{tabular}

${ }^{1}$ This study and Antia et al. (1999); ${ }^{2}$ Data from Bray et al. (2000), reported in Trull et al. (2001); ${ }^{3}$ Honjo and Mangannini (1993); ${ }^{4}$ Special Research Project (SFB313), Universtiy of Kiel, available at http://www.ifm.uni-kiel.de/jgofs/dm/. ${ }^{5}$ Dymond and Collier (1989); ${ }^{6}$ Dymond and Collier (1999); ${ }^{7}$ Noji et al. (1999); ${ }^{8}$ von Bodungen et al. (1991) n.g.=not given

decreased substantially, accounting for $61 \pm 20.4 \%, 34 \pm 23 \%$ and $15 \pm 3.4 \%$ of total phosphorus at $1440 \mathrm{~m}, 3220 \mathrm{~m}$ and
$4000 \mathrm{~m}$ respectively. Site-specific differences in dissolved phosphorus fluxes between these traps and literature values 
were small (Table 1), with a similar proportion of total phosphorus as DIP ex at two sites in the Norwegian Sea and East Greenland Sea (ca. $80 \%$ at $500 \mathrm{~m}$, decreasing to 68 and $40 \%$ at $3000 \mathrm{~m}$ and $2200 \mathrm{~m}$ respectively; von Bodungen et al., 1991). Lower $\mathrm{DIP}_{\mathrm{ex}}$ concentrations were found in the temperate north Atlantic at $34^{\circ} \mathrm{N}$ and $48^{\circ} \mathrm{N}$ along $21^{\circ} \mathrm{W}$, decreasing from $30-50 \%$ at $1000 \mathrm{~m}$ to $17 \%$ at $3700 \mathrm{~m}$ and $10 \%$ at $4500 \mathrm{~m}$. Weak linear correlations between particulate organic phosphorus and DIP ex were found at all sites (Fig. 1).

Since samples were processed a minimum of 5 months after sample retrieval a time-course of increase in dissolved elemental concentrations in supernatent could not be investigated. After the initial analyses in 1994, splits and supernatent were stored at $4^{\circ} \mathrm{C}$ in the dark and reanalyzed in 2004 for selected variables. During this long-term storage particulate organic phosphorus showed no decrease, indicating that further degradation or leaching did not occur. For particulate organic phosphorus measured in $1994\left(\mathrm{POP}_{1994}\right)$ and the measurements repeated in $2004\left(\mathrm{POP}_{2004}\right)$ the following relationship was found:

$\mathrm{POP}_{1994}=0.09( \pm 0.07)+1.03( \pm 0.28) \mathrm{POP}_{2004} ; \mathrm{n}=136$, $r^{2}=0.89$.

\subsection{Excess silicate in supernatant}

High excess dissolved silicate $\left(\mathrm{DSi}_{\mathrm{ex}}\right)$ concentrations were found in all traps studied (Fig. 2). Maximum $\mathrm{DSi}_{\mathrm{ex}}$ values in supernatent of ca. 1000-1200 $\mu \mathrm{M}$ (at which concentration silicate saturates in seawater at ca. $2^{\circ} \mathrm{C}$ and $\mathrm{pH} 8$, Rickert et al., 2002) were seen, with the initial slope of PSi to DSi $i_{e x}$ decreasing with increasing water depth. Maximal losses of $\mathrm{SiO}_{2}$ to the dissolved phase at the $500 \mathrm{~m}$ horizon amounted to between $61( \pm 7.4) \%$ at the OMEX 3 site and $35( \pm 21.1) \%$ in the Norwegian Sea. Below $3500 \mathrm{~m}$ a relatively constant fraction $(6.1-6.7 \%)$ of the total siliceous flux was found as $\mathrm{DSi}_{\text {ex }}\left(\right.$ OMEX 4 at $4000 \mathrm{~m} ; 34^{\circ} \mathrm{N}, 21^{\circ} \mathrm{W}$ at $4500 \mathrm{~m} ; 47^{\circ} \mathrm{N}$, $21^{\circ} \mathrm{W}$ at $\left.3700 \mathrm{~m}\right)$. Remarkably low dissolution of $\mathrm{SiO}_{2}$ into supernatent $(<5$ to $10 \%)$ was seen in traps from the Southern Ocean at $51^{\circ} \mathrm{S}$ and $53^{\circ} \mathrm{S}$, up to an order of magnitude lower than the other sites at similar depth.

\subsection{Excess nitrogen in supernatant}

For nitrogen too substantial excess concentrations in supernatent were seen. Excess dissolved inorganic nitrogen $\left(\mathrm{DIN}_{\mathrm{ex}}=\right.$ excess $\mathrm{NO}_{3}+\mathrm{NH}_{4}^{+}$) was low (ranging from 1.5 to $5.4 \%$ of total nitrogen, Fig. 3 and Table 1) and consisted almost exclusively of $\mathrm{NH}_{4}^{+}$. Excess dissolved organic nitrogen $\left(\mathrm{DON}_{\mathrm{ex}}\right)$ accounted by far for the bulk of dissolved nitrogen species and amounted to $45( \pm 13) \%$ and $16.7( \pm 2.9) \%$ of total nitrogen fluxes in the traps at $600 \mathrm{~m}$ and $4000 \mathrm{~m}$, respectively (Fig. 4a). DON $\mathrm{Nx}_{\mathrm{ex}}$ was linearly related to PON fluxes and showed a decreasing trend as proportion of total nitrogen flux with trap depth.

\subsection{Excess carbon in supernatant}

A similar trend was observed for excess dissolved organic carbon $\left(\mathrm{DOC}_{\mathrm{ex}}\right)$ in supernatent, in that it was linearly related to POC flux and decreased with increasing trap depth (Fig. 4b). Altogether, $30( \pm 6.6) \%$ and $7( \pm 3.6) \%$ of total carbon was found as $\mathrm{DOC}_{\mathrm{ex}}$ at $600 \mathrm{~m}$ and $4000 \mathrm{~m}$, respectively. Dissolved inorganic carbon (DIC) was not measured since the cup water was buffered, precluding measurements of the carbonate system. However, an attempt is made to judge the extent of the problem by assuming (as a first approximation) that continual respiration after particles settle in the jars would produce dissolved inorganic carbon (DIC) and nitrogen (DIN) whereas enzymatic degradation and leaching from particles would give out dissolved organic carbon (DOC) and nitrogen (DON), roughly in the Redfield C:N ratio of 6.6:1. Thus, multiplying the DIN concentration by 6.6 the ammount of DIC produced in the traps would be $55-316 \mu \mathrm{M}$, or 2.8 $4.3 \%$ of particulate organic carbon (POC) flux and $1.7-3.3 \%$ of total organic carbon (POC+DOC) flux.

Excess dissolved $\mathrm{Ca}\left(\mathrm{DCa}_{\mathrm{ex}}\right)$ was measured to check for inorganic carbon losses from the particles; there was an increase of 3.9-7.9\% in supernatant above background dissolved $\mathrm{Ca}$ levels $(9.9 \%$ at $1440 \mathrm{~m})$. As mentioned, in buffered systems alterations in $\mathrm{pH}$, that would indicate changes in the DIC and alkalinity pools due to calcite dissolution and respiration (that have opposing effects on $\mathrm{pH}$ ), cannot be used. In unbuffered systems however, a rough calculation (made using the "CO2SYS" program of E. Lewis) indicates that these could cancel each other, resulting in a small loss of calcite at constant $\mathrm{pH}$ values. For example, the dissolution of calcite in the traps studies (on average $3 \mathrm{mg}$ calcium per 400-ml cup) would produce an alkalinity increment of $350 \mu \mathrm{eqt} / 1$ and DIC change of $175 \mu \mathrm{M}$. At a temperature of $4^{\circ} \mathrm{C}$, and initial DIC and Alkalinity values of 2100 and $2300 \mu \mathrm{M}$, respectively, this would increase $\mathrm{pH}$ by 0.2 units. Back-calculating the amount of respiration that would be needed "balance" this (i.e. bring pH back to the original value) yields $111 \mu \mathrm{M}$ DIC added due to respiration. This is within the range (55-316 $\mu \mathrm{M}$ DIC) estimated to result from respiration in the cups (see previous paragraph). Nonetheless, these processes would have a small effect on total solubilization losses since most organic carbon is lost as DOC with the calcite losses being relatively small. This approach may be useful in shallow, short-term trap deployments where additional measurements of oxygen depletion could be used to constrain the extent of respiration in the jars.

\subsection{Swimmer-related excess dissolved fluxes}

For the trap at $600 \mathrm{~m}$, where maximal swimmers were found, there was no correlation between swimmer carbon (a better estimation of swimmer flux than numbers alone) and DOC or DON values $\left(\mathrm{r}^{2}=0.17, \mathrm{n}=37\right)$. At this depth, swimmer biomass was low compared to total organic carbon and 

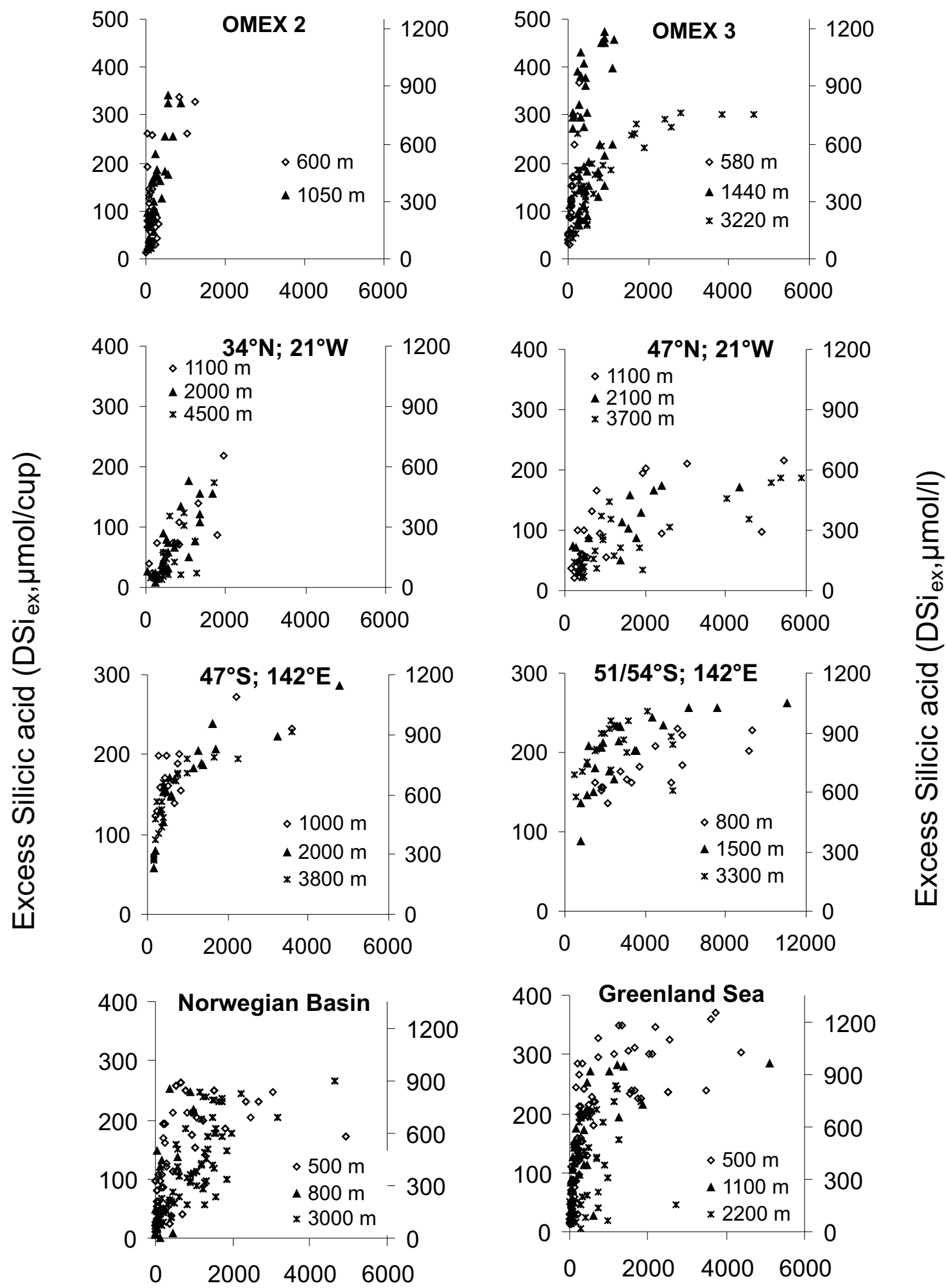

Particulate Silica Flux (PSi, $\mu \mathrm{mol} / \mathrm{cup})$

Fig. 2. Relationship between particulate biogenic silica (PSi; $x$-axes) and excess dissolved silicic acid (DSiex, left axes) in sediment trap samples at different sites and depths as listed in Table 1. The absolute concentration of silicate in supernatant water is given on the right axes. 

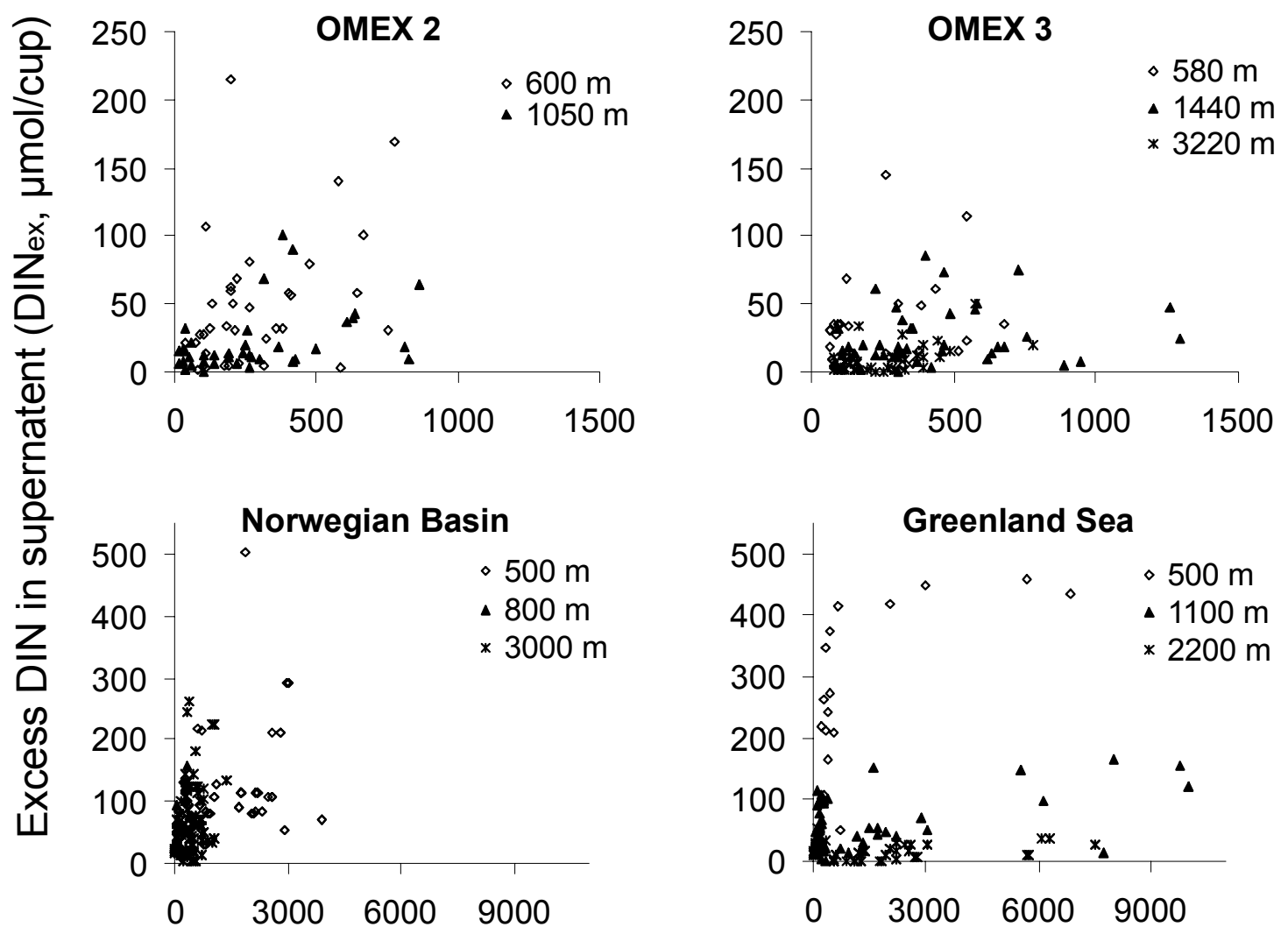

\section{Particulate Organic Nitrogen Flux (PON, $\mu \mathrm{mol} / \mathrm{cup}$ )}

Fig. 3. Relationship between particulate organic nitrogen (PON) and excess dissolved inorganic nitrogen (ammonium and nitrate) (DIN $\mathrm{ex})$ in sediment trap cups at different sites and depths as listed in Table 1.

nitrogen fluxes, accounting for a mean of $10.9( \pm 7.1) \%$ of total carbon (DOC+POC) in the traps. Even assuming that $20 \%$ of the swimmer biomass leached into the surrounding seawater, this effect would be negligible on DOC increase. The contribution of swimmers has therefore been neglected and it is assumed that the excess DOC and DON originated only from passively sinking particles.

\subsection{Correction of $\mathrm{C}: \mathrm{N}: \mathrm{P}, \mathrm{N}: \mathrm{Si}$ and POC:PIC ratios}

Table 2 summarizes the molar ratios of $\mathrm{C}: \mathrm{N}: \mathrm{P}$ for the traps analyzed in this study as well as other values from the literature. Relying on information from particulate analyses only, the C:P and N:P ratios are highly in excess of the Redfield value of 106:1 and 16:1 respectively, even though the scatter in the data is large. Where corrections for the dissolved fluxes are available for all elements, mean ratios at the base of the mixed layer are in good agreement with the Redfield ratios, increasing with depth to $4000 \mathrm{~m}$. Large shifts in the POC:PIC ratio are seen when accounting for excess dissolved fluxes, increasing from 2:1 to a mean of 7:1 at $600 \mathrm{~m}$. For nitrogen and silica, similar rates of dissolution result in large corrections of the absolute flux values but the ratio of $\mathrm{N}$ :Si remains unchanged (Table 3).

\section{Discussion}

The presence of excess dissolved material in the trap supernatent water is the most direct evidence that particles settled within the cups are altered and solubilized during storage. No matter how these excess dissolved concentrations result: from continual particle degradation, passive leaching of aggregate pore fluids, through gradual physical breakdown of dead membranes and organic entities, or through chemical dissolution such as for silica and calcium carbonate, a correct estimation of the flux reaching the traps requires correction for this artifact. Determining the contribution of each of these processes to net solubilization is however important in considering traps deployed in differing environments with different conditions of sample storage, treatment and analyses. The analyses here is restricted to mid-water traps with low swimmer abundances, where long-term deployments and storage of samples allows a straightforward determination of 

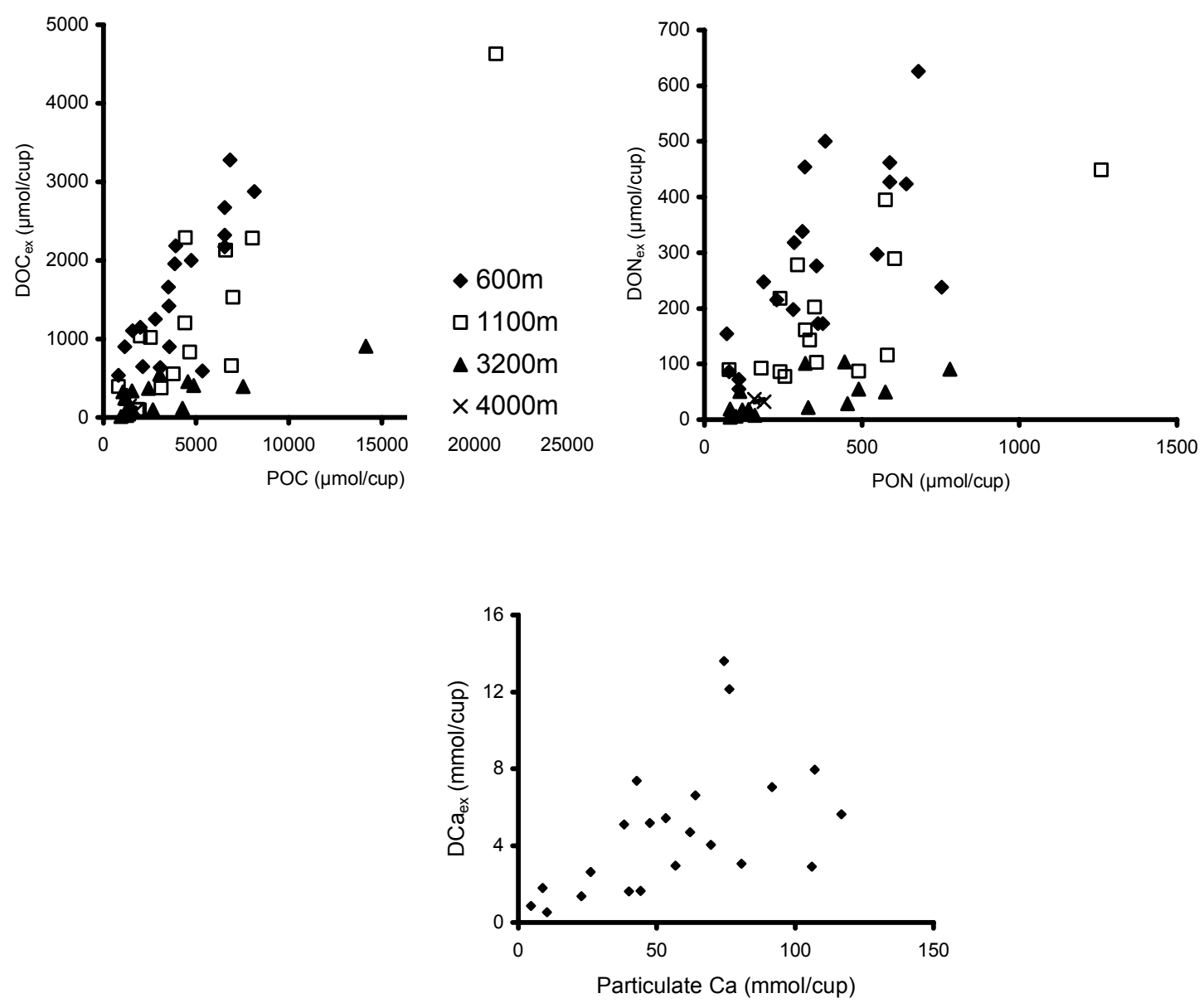

Fig. 4. Relationship between particulate organic carbon (a) and nitrogen (b) to the excess dissolved concentrations of organic carbon and nitrogen respectively. (c) Relationship between particulate calcium and excess dissolved calcium in trap samples. All data are from the OMEX traps only.

excess elements in supernatent. Shallow deployments for merely hours to days in high-swimmer environments would require a different approach, since swimmers are a major source of dissolved elements in such trap samples, and there is no reliable way to separate swimmer contribution of differing elements from that originating from the passive flux.

\subsection{Aggregates as "carriers" of dissolved elements}

The fact that large sinking aggregates, the main vehicles for vertical elemental fluxes (McCave, 1975; Fowler and Knauer, 1986), carry dissolved loads in their interstitial spaces has been recognized for some time. Aggregates are greatly enriched in DOM and inorganic products of remineralisation and dissolution such as phosphate and silicate (Shanks and Trent, 1979; Alldredge, 2000; Brzezinski et al., 1997; see Simon et al., 2002 for a summary). A substantial fraction of the dissolved loads leave the aggregates within the euphotic zone (Kiørboe et al., 2001). Nonetheless, where the rate of remineralisation by aggregate bacteria exceeds uptake of substrate and loss through outward diffusion, as found by Smith et al. (1992), pore fluids of aggregates are replenished faster than depleted. Fecal pellets, an important aggregate type, also contain large amounts of dissolved organic matter (DOM) that leach out into the surrounding seawater (UrbanRich, 1999). Packed with bacteria and heterotrophic protozoa (Silver and Alldredge, 1981; Simon et al., 2002), these micro-environments are hotspots of microbial activity in the water column and greatly affect the cycling of elements in the water column. Investigating the time-course microbial degradation of fresh diatom aggregates, Grossart and Ploug (2001) found significant carbon and nitrogen contents and high microbial turnover rates after 8 days of incubation, during which time aggregates in the natural environment would be well below the winter mixed layer.

As Alldredge (2000) points out, the dissolved loads in the interstitial spaces of aggregates must contribute substantially to vertical flux. However, practically all measurements of DOM within aggregates have been done within the upper 
Table 2. Atomic carbon:nitrogen:phosphorus $(\mathrm{C}: \mathrm{N}: \mathrm{P})$ ratios from the particulate fraction only and total (particulate + dissolved) material in sediment traps and from chemical analyses along isopycnals.

\begin{tabular}{|c|c|c|c|c|c|c|c|c|c|}
\hline \multirow[t]{2}{*}{ Site } & \multirow[t]{2}{*}{ Depth (m) } & \multicolumn{4}{|c|}{ Ratio in Particles Only } & \multicolumn{3}{|c|}{ Ratio of Total Flux } & \multirow[b]{2}{*}{$\mathrm{C}: \mathrm{N}$} \\
\hline & & C: & N: & $\mathbf{P}$ & $\mathrm{C}: \mathbf{N}$ & C: & $\mathbf{N}:$ & $\mathbf{P}$ & \\
\hline European Continental Margin ${ }^{1}$ & 600 & $724 \pm 353$ & $85 \pm 30$ & 1 & $8.3 \pm 2.0$ & $104 \pm 70$ & $17 \pm 7,9$ & 1 & $5,6 \pm 1,6$ \\
\hline$"$ & 1100 & $464 \pm 291$ & $56 \pm 33$ & 1 & $9.1 \pm 2.0$ & $187 \pm 110$ & $25 \pm 8,4$ & 1 & $6,5 \pm 1,6$ \\
\hline$"$ & 580 & $915 \pm 426$ & $94 \pm 44$ & 1 & $9.2 \pm 2.1$ & $107 \pm 69$ & $15 \pm 8,0$ & 1 & $6,1 \pm 1,2$ \\
\hline$"$ & 1440 & $524 \pm 338$ & $52 \pm 32$ & 1 & $9.6 \pm 2.9$ & $206 \pm 130$ & $30 \pm 17,6$ & 1 & $6,9 \pm 1,9$ \\
\hline$”$ & 3220 & $317 \pm 181$ & $33 \pm 16$ & 1 & $9.7 \pm 2.4$ & $236 \pm 112$ & $29 \pm 12,5$ & 1 & $7,8 \pm 2,1$ \\
\hline$"$ & 4000 & 282 & 26 & 1 & 11.3 & 196 & 28 & 1 & 8,1 \\
\hline Norwegian Basin ${ }^{2}$ & 400 & 730 & 49 & 1 & 16.3 & & & & \\
\hline 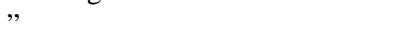 & 800 & 321 & 25 & 1 & 13.1 & & & & \\
\hline$"$ & 2950 & 345 & 17 & 1 & 22.6 & & & & \\
\hline East Greenland Current ${ }^{3}$ & 500 & 647 & 59 & 1 & 9.6 & & & & \\
\hline$"$ & 500 & 1053 & 84 & 1 & 9.4 & & & & \\
\hline$"$ & 500 & 622 & 71 & 1 & 8.2 & & & & \\
\hline$"$ & 1000 & 331 & 33 & 1 & 8.5 & & & & \\
\hline$"$ & 2200 & 226 & 30 & 1 & 8.9 & & & & \\
\hline$"$ & 2310 & 171 & 19 & 1 & 10.3 & & & & \\
\hline Gulf of Riga 4 & 30 & 426 & 49 & 1 & 9.3 & & & & \\
\hline Gotland Sea 5 & 140 & 82 & 9 & 1 & 9.3 & & & & \\
\hline N. Baltic Sea ${ }^{6}$ & 40 & 9 to 13 & 5 to 22 & 1 & & & & & \\
\hline SargassoSea ${ }^{7}$ & 150 & 457 & 46 & 1 & 8.6 & & & & \\
\hline$"$ & 150 & 340 & 42 & 1 & 8.3 & & & & \\
\hline$"$ & 300 & 429 & 58 & 1 & 7.4 & & & & \\
\hline$"$ & 300 & 382 & 62 & 1 & 14.0 & & & & \\
\hline Tasmanian $\mathrm{Sea}^{8}$ & 300 & 159 & 15 & 1 & 10.8 & & & & \\
\hline$"$ & 1000 & 129 & 13 & 1 & 9.7 & & & & \\
\hline$"$ & 300 & 193 & 22 & 1 & 8.8 & & & & \\
\hline$"$ & 1000 & 232 & 22 & 1 & 10.5 & & & & \\
\hline $48^{\circ} \mathrm{N}^{9}$ & 1000 & 968 & 110 & 1 & 8.8 & & & & \\
\hline $34^{\circ} \mathrm{N}^{9}$ & 1000 & 430 & 74 & 1 & 5.8 & & & & \\
\hline Sargasso Sea ${ }^{10}$ & 3694 & 104 & 10 & 1 & 10.4 & & & & \\
\hline tropical Atlantic ${ }^{10}$ & 389 & 182 & 21 & 1 & 8.8 & & & & \\
\hline$"$ & 976 & 274 & 31 & 1 & 8.9 & & & & \\
\hline$"$ & 3755 & 180 & 18 & 1 & 10.3 & & & & \\
\hline$"$ & 5068 & 202 & 20 & 1 & 10.3 & & & & \\
\hline East Hawaii ${ }^{10}$ & 378 & & & 1 & 9.0 & & & & \\
\hline 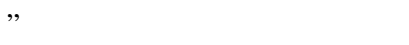 & 978 & & & 1 & 9.2 & & & & \\
\hline$"$ & 2778 & 303 & 30 & 1 & 10.1 & & & & \\
\hline$"$ & 4280 & 243 & 10 & 1 & 10.4 & & & & \\
\hline$"$ & 5582 & & & 1 & 9.2 & & & & \\
\hline Panama Basin ${ }^{10}$ & 667 & 318 & 33 & 1 & 9.6 & & & & \\
\hline$"$ & 1268 & 226 & 26 & 1 & 8.8 & & & & \\
\hline$”$ & 2700 & 210 & 25 & 1 & 9.2 & & & & \\
\hline$"$ & 3700 & 243 & 23 & 1 & 10.2 & & & & \\
\hline \multicolumn{10}{|c|}{ Estimates from chemical data along isopycnals: } \\
\hline N. Atlantic ${ }^{11}$ & $200-500$ & & & & & $97 \pm 9$ & $17.6 \pm 0.6$ & 1 & 5,5 \\
\hline$"$ & $500-680$ & & & & & $88 \pm 6$ & $16.8 \pm 0.5$ & 1 & 5,2 \\
\hline Atlantic, Indian, Pacific Ocean ${ }^{12}$ & $500-1000$ & & & & & $117 \pm 14$ & $16 \pm 1$ & 1 & \\
\hline N. Atlantic 13 & $200-500$ & & & & & $101 \pm 12$ & $14.4 \pm 0.7$ & 1 & $7.2 \pm 0.4$ \\
\hline$"$ & $500-680$ & & & & & $131 \pm 18$ & $16.8 \pm 1.3$ & 1 & $7.8 \pm 0.5$ \\
\hline
\end{tabular}

${ }^{1}$ This study, ${ }^{2,3}$ Special Research Project (SFB313), Universtiy of Kiel, available at http://www.ifm.uni-kiel.de/jgofs/dm/ . ${ }^{4}$ Reigstad et al. (1999) ${ }^{5}$ Struck et al. (2004). ${ }^{6}$ Heiskanen et al. (1998) ${ }^{7}$ Oceanic Flux Program of WHOI, (http://www.whoi.edu/science/MCG/ofp/) ${ }^{8}$ Trull et al. (2001) ${ }^{10}$ Honjo and Mangannini (1993) ${ }^{11}$ Takahashi et al. (1985) ${ }^{12}$ Anderson and Sarmiento (1994) ${ }^{13}$ Körtzinger et al. (2001b) 
Table 3. Ratios of particulate organic carbon: particulate inorganic carbon (POC:PIC) and atomic nitrogen: silica (N:Si) ratios from the particulate fraction only and total (particulate + dissolved) material in sediment traps.

\begin{tabular}{lccccc}
\hline Site & Depth $(\mathrm{m})$ & \multicolumn{2}{c}{ Ratio in particles only } & \multicolumn{2}{c}{ Ratio in total material } \\
& & $\mathrm{C}_{\text {org }}: \mathrm{C}_{\text {inorg }}$ & $\mathrm{N}: \mathrm{Si}$ & $\mathrm{C}_{\text {org }}: \mathrm{C}_{\text {inor }}$ & $\mathrm{N}: \mathrm{Si}$ \\
\hline European Continental Margin & 600 & $2,0 \pm 1,2$ & $2,2 \pm 1,1$ & $6,1 \pm 3,3$ & $2,4 \pm 1,3$ \\
, & 1100 & $2,1 \pm 1,9$ & $1,3 \pm 0,9$ & $6,4 \pm 3,5$ & $1,3 \pm 0,8$ \\
, & 580 & $2,1 \pm 0,6$ & $3,4 \pm 1,9$ & $8,0 \pm 1,7$ & $2,5 \pm 1,3$ \\
, & 1440 & $2,8 \pm 2,5$ & $0,9 \pm 0,6$ & $4,3 \pm 1,7$ & $1,0 \pm 0,5$ \\
$\Longrightarrow$ & 3220 & $1,3 \pm 0,8$ & $0,4 \pm 0,2$ & $2,6 \pm 1,1$ & $0,4 \pm 0,2$ \\
$\#$ & 4000 & 0,8 & 0,4 & 1,1 & 0,4 \\
\hline
\end{tabular}

water column; the DOM load in sub-surface and deep aggregates is unknown. The data presented here provide a first, albeit indirect, estimate of dissolved elemental concentrations in large particles in the mid- and lower water column. Aggregates are thus carriers of significant amounts of dissolved material, here called the "particle-associated dissolved flux".

The data here can be compared to those of Alldredge (2000) who measured POC and DOC on aggregates from 2-20 m water depth. At these shallow depths DOC was on average $31 \%$ of total carbon in the particles whereas in trap material at $600 \mathrm{~m}$ depth (this study) $\mathrm{DOC}_{\mathrm{ex}}$ was on average $30 \%$ of total carbon in the cups, suggesting that a significant proportion of labile organic carbon is still being recycled within aggregates reaching the base of the mixed layer, and that losses due to leaching, diffusion and assimilation by organisms on and in the aggregates are lower than the net DOC production rates as shown by Smith et al. (1992). Considerably lower $\mathrm{DOC}_{\mathrm{ex}}$, accounting for $<10 \%$ total carbon, is exported below $1400 \mathrm{~m}$ (Fig. 4a). The linear relationship between POC flux and $\mathrm{DOC}_{\mathrm{ex}}$ implies no significant seasonality in the contribution of dissolved matter to total fluxes, but rather a constant internal aggregate remineralisation by bacteria and protozoa, in proportion to organic matter availability.

\subsection{Particle alteration in trap jars}

Aside from passive leaching out of large particles, other processes such as continued microbial degradation, the activity of free hydrolytic enzymes, physical destruction of dead organisms and damaged membranes and chemical dissolution could also contribute to the excess concentrations of dissolved elements measured. Particle breakdown by microbial activity is assumed to be stopped by the addition of poison to the cup solution, but this may not be instantaneous. Although at the concentration of mercuric chloride used in this study Lee et al. (1992) reported cessation of microbial activity in a concentrated particle suspension, penetration of the poison into aggregates would be rate-limited by the diffusion coefficient applicable. There is little data on the diffusion constants applicable for aggregates, but these are likely to be considerably slower than for single cells due to the frac- tal, mucous/gel structure of organic aggregates. Brzezinski et al. (1987) estimated 2 orders of magnitude slower diffusivity rates for silica from diatom aggregates than those for elemental silica through a permeous membrane. This considerably slower transport for solutes into aggregates could result in some continuation of microbial degradation before poison concentrations in the aggregates become effective.

Free enzymes such as phosphatases and proteases are also concentrated in aggregates and though their activity is strongly inhibited by both mercuric chloride and formaldehyde at the concentrations used to poison trap samples (Christian and Karl, 1995; Liu et al., 1997), the same time constraints on penetration of poison as discussed above would apply. In as far as free phosphatases degrade larger dissolved organic entities to phosphate and low molecular weight organic material (Hoppe, 2003), they would contribute to alteration and not production of dissolved species.

For silica and calcium, where dissolution is controlled both by physico-chemical factors as well as biological degradation, dissolution and leaching may continue after microbial activity is stopped. Silica dissolution on organic aggregates is accelerated by destruction of the organic frustule matrix through bacterial protease activity (Bidle and Azam, 2001), and diatomaceous aggregates in the upper water column accumulate silicate in their interstitial spaces at up to 100fold higher concentrations than in the surrounding seawater (Brzezinski et al., 1997). Although seawater is greatly undersaturated with respect to silicic acid, high siliceous fluxes and leaching out of particles cause saturation of silicate in supernatent water (Fig. 2), presumably stopping further losses. Bauerfeind and von Bodungen ${ }^{1}$ show the dissolution kinetics of silicate in sediment traps with a clear saturation at high particulate silica fluxes similar to that recorded here.

During processing of trap samples (picking of swimmers, splitting and filtering), particles are rinsed with seawater and partially broken, and particularly during filtering the interstitial spaces are bled. However, presuming equilibrium between the particles and surrounding seawater during

\footnotetext{
${ }^{1}$ Bauerfeind, E. and von Bodungen, B.: Loss of biogenic particulate silicon in sediment trap samples through dissolution - does it matter? Marine Geology, in review, 2005.
} 
the long storage times used here, adding the excess elemental fluxes in supernatent to the measured particulate flux accounts for this loss. Filtration of particles prior to analysis, whether from water bottles, trap jars or in situ pumps, causes loss of interstitial fluids and underestimation (to some as yet unknown degree) of their elemental loads. This "particleassociated dissolved load" is not measured in either the particulate or dissolved pool using current protocols, and is potentially missing in estimates of elemental standing stocks and vertical flux. This caveat is common to all analyses of particles in the water column and warrants attention in all biogeochemical studies.

\subsection{Factors affecting differences in solubilization}

Factors such as fixative/poison type, brine, buffer, and presence of swimmers are likely to affect leaching of interstitial fluids. Where data are available (Table 1), traps with similar treatments (e.g. traps in the Greenland Sea, Norwegian Sea and European Continental Margin all had mercuric chloride, with no brine addition), similar proportions of excess dissolved phosphorus and silicate were found in supernatent at similar depths. For silicate, traps in the Southern Ocean showed significantly lower $\mathrm{DSi}_{\mathrm{ex}}$ concentrations as compared to those from other areas; however, since both the species composition and biogeochemical regimes as well as trap treatment (addition of brine in the Southern Ocean traps) differed, it is difficult to separate these effects. For traps at similar sites and depths (the OMEX traps and data from Honjo and Manganini, 1993), there are factor of 2 differences in the slopes of dissolved to particulate fluxes of phosphorus and silicon measured (Figs. 1 and 2), with higher proportions of dissolved elements in the mercuric-chloridepoisoned OMEX traps. These may be due to differences in poison/fixative used since formaldehyde is known to stabilize membranes and chitinous structures, possibly making them less permeable for leaching (e.g. Lee et al., 1992). Rather unfortunately, the use of formaldehyde as a fixative, as recommended by the JGOFS protocols (http://usjgofs.whoi.edu/ protocols_rpt_19.html) precludes DOC/DON measurements in supernatant, the effect of which can be substantial in the mesopelagic zone.

For silica in particular, the initial slope of $\mathrm{DSi}_{\mathrm{ex}}$ against PSi flux varies both with depth and site. At $51^{\circ} \mathrm{S}$ in the Southern Ocean where the large, heavily silicified Fragillariopsis kerguelensis dominated diatom export (Trull et al., 2001), the silica dissolution was half of that found at other sites at the same depths. Such site-specific differences in dissolution of biogenic silica has been reported by Rickert et al. (2002) who found a factor of 10 lower dissolution of silica in the Southern Ocean as compared to the Norwegian Sea, related to differences in the reactivity of diatom shells. Species-specific differences in the dissolution of diatom frustules (Kohly, 1998), and strong differences in reactivity of biogenic silica linked to the structural integrity, organic coat- ing and detrital minerals are manifested in higher silica contents of Southern Ocean sediments as compared to similar latitudes in the North Atlantic (Schlüter et al., 2000).

Although in this study swimmer fluxes were low and negligible compared to the passive sinking fluxes, swimmers may strongly falsify results in shallow traps (Steinberg et al., 1998), where swimmer biomass may equal or exceed the passive sinking flux. Addition of brine, that causes zooplankton swimmers to herniate in the traps (Peterson and Dam, 1990), would magnify the problem. Since swimmers, through herniation, excretion and leaching will introduce large dissolved concentrations that cannot reliably be separated from the fraction originating from sinking particles, swimmer avoidance should be a priority. For very short term deployments of shallow traps solubilization may not present a major problem for all elements, but at present little is know about this problem.

For elements other than those presented here, the rate and degree of dissolution would need to be individually determined. Knauer et al. (1984) showed rapid dissolution of up to $>80 \%$ and $>70 \%$ of sedimenting manganese and cadmium respectively and similarly high dissolution, although proceeding at a slower rate, for zinc. Pohl et al. (2004) found only half those values in their traps. Particle-reactive elements such as iron and thorium are, predictably, not found in supernatant (Pohl et al., 2004). These results imply that the application of Th:POC ratios from traps to estimate fluxes based on radionucleide profiles would require an estimate of the relative losses of these elements to the dissolved phase.

Given the differing stoichiometry of POM and DOM and the different time scales of their production and mineralisation (Hopkinson and Vallino, 2005) large aggregates as carriers of both particulate and dissolved material should be treated as a single entity requiring a consolidated analytical approach. This would include collection of interstitial waters during filtration with analyses of excess dissolved elements, as has been done in the upper water column in but relatively few studies (Brzezinski et al., 1997; Alldredge 2000).

\section{4 "Correcting" for particle solubilization}

Correcting for solubilization losses from particles can have severe to negligible effects depending on element and trap depth, both in terms of the absolute values of flux as well as the stoichiometry of settling material (Tables 2 and 3). Whereas at the base of the winter mixed layer at around $500 \mathrm{~m}$, phosphorus would need to be corrected upwards by a factor of up to 10, carbon and nitrogen flux corrections are between factors of 1.4 to 2 . Higher dissolution of silica would bring the total silica fluxes up by a factor of 2 to 2.5. Total calcium fluxes are practically unaffected by solubilization. The "correction factors" are similar to the errors due to hydrodynamic biases of moored traps, estimated by water column radioisotope budgets below the mixed layer (Scholten et al., 2001; Yu et al., 2001). For the OMEX traps, 
for example, Scholten et al. (2001) estimate collection efficiencies of ca. $38 \%$ at $600 \mathrm{~m}$ at both mooring sites, $90 \%$ at $1050 \mathrm{~m}$ at OMEX 2 and $113 \%$ and $128 \%$ at $1440 \mathrm{~m}$ and $3220 \mathrm{~m}$ at OMEX 3. As these authors pointed out, these estimates are to be treated with caution, since no direct measurements in the water column were available at these sites and because of their proximity to the shelf edge, where particularly in the deeper traps lateral advection could have caused the "overtrapping" signal. Nonetheless, it should be pointed out that this correction, based on calculated and measured fluxes of ${ }^{230} \mathrm{Th}$, is unaffected by solubilization since thorium has a high affinity for particles and is not found in supernatent water (Pohl et al., 2004). The factor of 2.5 "correction" based on the thorium budgets for the $600 \mathrm{~m}$ traps is similar in magnitude to that for organic carbon and nitrogen and slightly lower than that for phosphorus when accounting for solubilization. Both these effects (solubilization and hydrodynamic biases) decrease with increasing water depth and, when accounted for, will increase the estimates of mid-water remineralisation rates that have been derived from sediment trap data (e.g. Martin et al., 1987; Antia et al., 2001). These "corrections", by increasing export estimates, may narrow the gap between measured particle fluxes and those based on subsurface oxygen utilization rates (e.g. Jenkins, 1982). They would also substantially decrease the estimated "lateral" or "advective" fluxes that are assumed where an increase in flux with depth is measured (e.g. Neuer et al., 1997; Antia et al., 1999) and narrow the observed discrepancy between vertical POC fluxes and sediment community carbon demand (Lampitt et al., 1995; Smith et al., 2001). Central to the need or even ability to correct for solubilization, trap collection bias or other artifacts is our confidence in the level of accuracy with which we can measure sinking fluxes and the level of accuracy that is needed for the process to be investigated. With more attention being paid to methodological refinements and calibration of trap behavior under various conditions, a higher level of accuracy can be achieved by applying appropriate protocols for measurement of the collected particles.

\subsection{Elemental ratios in total (dissolved + particulate) flux}

The ratio of major elements (organic- and inorganic carbon, nitrogen, phosphorus and silicon) leaving the upper mixed layer is crucial in estimating the net sequestration potential of the biological pump and the global distribution of deep-water nutrient ratios. Biogeochemical models routinely use nitrate fluxes to estimate carbon export (e.g. MacCready and Quay, 2001) relying on the mean global validity of the Redfield stoichiometry of C:N uptake in organic matter. Although there is evidence that, at least seasonally, particle formation with a C:N ratio significantly higher than the Redfield Ratio takes place (Körtzinger et al., 2001a; Engel et al., 2002) the present analysis indicates that export at the base of the mixed layer does not reflect this in the annual mean, at least in the North
Atlantic. More such investigations are required from other areas.

A large amount of data on the elemental ratios of sinking particles arising from sediment traps (summarized in Table 2) uniformly shows $\mathrm{C}: \mathrm{N}$ ratios above the Redfield Ratio at the base of the mixed layer. In a compilation of trap and in situ pump data Schneider et al. (2003) reported particulate $\mathrm{C}: \mathrm{N}$ ratios above 8.5 below $500 \mathrm{~m}$ depth, increasing by 0.2 per $1000 \mathrm{~m}$. The OMEX data reported here are in agreement with this trend for the particulate fraction only. However when corrected for dissolved $\mathrm{C}, \mathrm{N}$ and $\mathrm{P}$ in the traps the elemental ratios are almost exactly 106:16:1 (Table 1). Total C:N ratios not significantly different from the Redfield value $(6.1 \pm 1.2)$ at $600 \mathrm{~m}$ depth at this site are also in agreement with those calculated by Körtzinger et al. (2001b) along isopycnals at similar depths in the North Atlantic (6.5 \pm 0.2$)$. Körtzinger et al. (2001b) in turn revised the previously lower estimate (C:N of $5.1 \pm 0.2: 1)$ of Takahashi et al. (1985) by subtracting the contribution of anthropogenic $\mathrm{CO}_{2}$ to total DIC. Total N:P ratios of ca. 16:1 and N:Si ratios of 2.4:1 in sedimenting material at the base of winter mixed layer also agree with long-term means of dissolved nutrients in the mesopelagic zone in the eastern North Atlantic (data from the Levitus Web site http://ingrid.ldeo.columbia.edu/ SOURCES/.LEVITUS/). This shows some consistency in the nutrient stoichiometry of material supply to and remineralization within the subsurface layers, whereas the exceedingly high $\mathrm{N}: \mathrm{P}$ ratios estimated in the particulate flux fraction only (averaging $\mathrm{N}: \mathrm{P}$ of $90: 1$ at $600 \mathrm{~m}$ ) deviate substantially from the canonical Redfield value.

The depth scales and relative remineralization profiles of carbon, nitrogen and phosphorus as estimated using numerical solutions to large-scale distributions of dissolved nutrients and oxygen in model studies (e.g. Anderson and Sarmiento, 1994; Schaffer, 1996; Schaffer et al., 1999) suggest ratios more in conformity to the globally averaged values reported by Redfield and colleagues than those reported for the particulate flux using sediment traps (Table 3). However, some uncertainty persists as to the changes in these remineralization ratios with depth; whereas Anderson and Sarmiento (1994), Takahashi et al. (1985) and Körtzinger et al. (2001b) find near-constant remineralization ratios with depth, Schaffer (1996) and Schaffer et al. (1999) estimate significant fractionation during remineralization of sinking organic matter in the upper $1500 \mathrm{~m}$ of the water column, with nutrients being released faster (i.e. shallower) than inorganic carbon. If the efficiency of the biological pump is defined as the amount of carbon per mole of limiting nutrient exported to below the depth of maximal mixing, this efficiency will depend on the $\mathrm{C}: \mathrm{N}: \mathrm{P}$ ratio of material exported from the euphotic zone as well as the relative remineralization of carbon and nutrients between the base of the euphotic zone and the depth of maximal annual mixing. The elemental stoichiometry of sinking particles is thus an important variable in the biogenic $\mathrm{CO}_{2}$ flux between the ocean 
and atmosphere. A preferential remineralization of nutrients to carbon in the mesopelagic zone would thus imply an efficiency of biological carbon drawdown in excess of that assumed using the Redfield ratios. If, by accounting for solubilization losses from sinking particles caught in sediment traps, the changing elemental composition of the sinking flux can be estimated, traps may provide reliable estimates of mesopelagic particle stoichiometry and remineralization ratios. Additionally, by providing material to characterize the composition and drivers of flux they are capable of yielding a more mechanistic understanding of upper ocean processes that effect the efficiency of the biological pump than largescale nutrient fields can be expected to provide.

For calcite, losses from the particles are low and relatively constant. Lower solubilization of this inorganic carbon as compared to the high $\mathrm{DOC}_{\mathrm{ex}}$ concentrations alters the Corg:Cinorg ratio (rain ratio) of flux at the base of the winter mixed layer (Table 2), that is responsible for net drawdown of atmospheric $\mathrm{CO}_{2}$ by the biological pump. Net carbon (sequestration) fluxes at the winter mixed layer at the OMEX site as defined and calculated by Antia et al. (2001) increase by $50 \%$ (from 1.47 to $2.22 \mathrm{mgC} \mathrm{m}^{-2} \mathrm{yr}^{-1}$ ) in reponse to the increase in the rain ratio from 2 to 7 at $600 \mathrm{~m}$ depth when accounting for the paticle-associated dissolved fluxes (Table 2). Integrated over basin-wide or global scales, this methodological caveat is significant.

Phosphorus fluxes are seldom reported in sediment trap studies, and indeed the extremely high C:P and N:P ratios found in the particulate fraction only (Table 1) are difficult to interpret. Even accounting for the more rapid remineralisation and loss of phosphorus from sinking particles compared to carbon and nitrogen, mid-water phosphate values present a constraint to loss rates that are far below those implied by $\mathrm{N}: \mathrm{P}$ ratios of over 50:1 at the base of the mixed layer (Table 2). At the OMEX sites revising the elemental export values to account for particle solubilization brings the values in agreement with mid-water N:P and N:Si ratios of $16: 1$ and $3: 1$, respectively (calculated from the Levitus data set). The ability to measure the $\mathrm{N}: \mathrm{P}$ and $\mathrm{C}: \mathrm{P}$ ratios of export is useful especially in regions where nitrogen is in chronic undersupply to the euphotic zone, and in coastal regions where phosphorus can limit phytoplankton growth. The commonly assumed excess carbon over nitrogen and nitrogen over phosphorus in winter mixed layer export reported from sediment traps may largely be an artifact of the measurements though more data are needed to confirm this conclusion from other sites.

Biogeochemical studies investigating the efficiency of the biological pump in atmospheric $\mathrm{CO}_{2}$ sequestration concentrate on the export of carbon to the limiting nutrient in excess of the Redfield value since this would supposedly enhance the oceans' role in the current climate debate. Should much of the "excess" fixed carbon be labile and respired near the surface, as is believed for the carbon-rich polysaccharide exudates of phytoplankton (Passow, 2002) this will have little effect on net carbon export. Possible sites of over-Redfield carbon export to below the mixed layer are thus most likely in the upwelling and high-productivity regions of the tropical ocean, where annual mixing is shallow and highest net sequestration fluxes are found (Antia et al., 2001). If sediment traps can be used to more reliably estimate the stoichiometry of export, a range of other analyses in the sedimenting particles they collect could give valuable insight into the biological control of export and regional deviations from the global mean. This warrants attention in further studies.

\section{Conclusions}

- Elevated concentrations of dissolved elements in sediment trap supernatent points to losses from the sinking particles caught and introduces errors in the total flux measurements if the particulate fraction only is measured. These errors are of the same order as those due to hydrodynamic biases in collection efficiency

- The effects of solubilization on measurements of total elemental fluxes range from negligible for particlereactive elements such as thorium and iron to substantial for rapidly recycled nutrients such as phosphorus

- For the major nutrients the degree of solubilization decreases in the order phosphorus, nitrogen, silica and carbon, and decreases with increasing water depth

- Element-specific differences in degree of solubilization results in errors in estimating the stoichiometry of export when the dissolved fraction is not measured

- Correcting for solubilization of the major nutrients results in revision of the $\mathrm{C}: \mathrm{N}: \mathrm{P}$ ratio of export from strongly phosphorus and slightly nitrogen-poor for the particulate fraction only to conform to the globally valid "Redfield Ratios" for the total (dissolved and particulate) fraction. This brings trap estimates in agreement with mid-water nutrient budgets and estimates of remineralisation along pycnoclines. The Rain Ratio (organic:inorganic carbon ratio) is also seen to be 4 -fold higher at the base of the winter mixed layer when solubilization is corrected for.

Acknowledgements. I am grateful to S. Krug and P. Fritsche for help with nutrient analyses, to K. Nagel and D. Schulz-Bull for DOC/DON analyses and R. Surberg for the dissolved Calcium analyses. I thank T. Trull, R. Peinert and C. Pohl for generously providing trap data in electronic form. Many thanks to the members of the SCOR Working Group 116 (K. Buesseler, T. Trull, S. Fowler, D. Steinberg, Ö. Gustafson, M. van den Loeff, M. Sarin, W. Gardner) for intensive discussions that contributed to this paper. Discussions with A. Körtzinger, C. Lamborg and U. Riebesell and editorial guidance by S. W. A. Naqvi improved the manuscript and are gratefully acknowledged.

Edited by: S. W. A. Naqvi 


\section{References}

Alldredge, A. L.: Interstitial dissolved organic carbon (DOC) concentrations within sinking marine aggregates and their potential contribution to carbon flux, Limnology and Oceanography, 45(6), 1245-1253, 2000.

Anderson, L. A. and Sarmiento, J. L.: Redfield Ratios of remineralisation determined by nutrient data analysis, Global Biogeochemical Cycles, 8, 65-80, 1994.

Antia, A. N., von Bodungen, B., and Peinert, R.: Particle flux across the mid-European continental margin. Deep-Sea Research, 46(12), 1999-2024, 1999.

Antia, A. N., Koeve, W., Fischer, G., et al.: Basin-wide particulate carbon flux in the Atlantic Ocean: regional export patterns and potential for atmospheric $\mathrm{CO}_{2}$ sequestration, Global Biogeochemical Cycles, 15, 845-862, 2001.

Armstrong, R. A., Lee, C., Hedges, J. I., Honjo, S., and Wakeham, S. G.: A new, mechanistic model for organic carbon fluxes in the ocean based on the quantitative association of POC with ballast minerals, Deep-Sea Research, 49, 2119-236, 2002.

Bauerfeind, E., Garrity, C., Krumbholz, M., Ramseier, R. O., and Voss, M.: Seasonal variability of sediment trap collections in the northeast water polynya, part 2 . biochemical and microscopic composition sedimenting matter. Journal of Marine Systems, 10(1-4), 371-389, 1997.

Bidle, K. D. and Azam, F.: Bacterial control of silicon regeneration from diatom detritus: significance of bacterial ectohydrolases and species identity, Limnology and Oceanography, 46, 16061623, 2001.

Bray, S., Trull, T., and Manganini, S.: SAZ project moored sediment traps: results of the 1997-1998 deployments, Antarctic CRC Research Report No. 15, 2000.

Brzezinski, M. A., Alldredge, A. A., and O'Bryan, L. M.: Silica cycling within marine snow, Limnology and Oceanography, 42, 1706-1713, 1997.

Buesseler, K. O.: Do upper-ocean sediment traps provide an accurate record of particle flux? Nature, 353(6343), 420-423, 1991.

Christian, J. R. and Karl, D. M.: Measuring bacterial ectoenzyme activities in marine waters using mercuric chloride as a preservative and a control, Marine Ecology Progress Series, 123, $217-$ 224, 1995.

Dymond, J. and Collier, R.: The easily soluble fraction of the settling particle flux, US GOFS Report No. 10, edited by: Knauer, G. A. and Asper, V., 1989.

Dymond, J. and Collier, R.: Particulate barium fluxes and their relationships to biological productivity, Deep-Sea Research (II), 43, 1283-1308, 1996

Dymond, J. and Collier, R.: Biogenic particle fluxes in the equatorial Pacific: Evidence for both high and low productivity during the 1982-1983 El Niño, Global Biogeochemical Cycles, 2, 129137, 1999.

Engel, A., Goldthwait, S., Passow, U., and Alldredge, A.: Temporal decoupling of carbon and nitrogen dynamics in a mesocosm diatom bloom, Limnology and Oceanography, 47(3), 753-761, 2002.

Fowler, S. W. and Knauer, G. A.: Role of large particles in transport of elements and organic compounds through the oceanic water column, Progress in Oceanography, 16, 147-197, 1986.

Gardner, W. D.: Sediment trap dynamics and calibration: A laboratory evaluation, Journal of Marine Research, 38, 17-39, 1980
Gardner, W. D., Hinga, K. R., and Marra, J.: Observations on the degradation of biogenic material in the deep ocean with implications on the accuracy of sediment trap fluxes, Journal of Marine Research, 41, 195-214, 1983.

Gardner, W. D.: Sediment trap technology and sampling in the surface waters, in: The changing ocean carbon cycle: midterm synthesis of the Joint Global Ocean Flux Study, edited by: Hanson, R. B., Ducklow, H. W., and Fields, J. G., Cambridge, 240-281, 2000.

Grasshoff, K., Kremling, K., and Erhardt, M. (Eds.): Methods of seawater analysis, 3rd Ed., Wiley-VCH, Weinheim, 1999.

Grossart, H. and Ploug, H.: Microbial degradation of organic carbon and nitrogen on diatom aggregates, Limnology and Oceanography, 46, 267-277, 2001.

Gust, G., Byrne, R. H., Bernstein, R. E., Betzer, P. R., and Bowles, W.: Particle fluxes and moving fluids: Experience from synchronous trap collection in the Sargasso sea, Deep-Sea Research, 39(7-8A), 1071-1083, 1992.

Gust, G., Bowles, W., Giordano, S., and Hüttel, M.: Particle accumulation in a cylindrical sediment trap under laminar and turbulent steady flow: An experimental approach, Aquatic Sciences, 58(4), 297-326, 1996.

Hansell, D. A., and Newton, J. A.: Design and evaluation of a "swimmer"-segregating particle interceptor trap, Limnology and Oceanography, 39(6), 1487-1495, 1994.

Heiskanen, A.-S., Haapala, H., and Gundersen, K.: Sedimentation and pelagic retention of particulate $\mathrm{C}, \mathrm{N}$ and $\mathrm{P}$ in the coastal northern Baltic Sea, Estuarine, Coastal and Shelf Science, 46, 703-712, 1998.

Honjo, S., Manganini, S. J., and Cole, J. J.: Sedimentation of biogenic mater in the deep ocean, Deep-Sea Research, 29, 609-625, 1982.

Honjo, S. and Manganini, S.: Annual biogenic particle fluxes to the interior of the north Atlantic ocean studied at $346 \circ \mathrm{N} 21^{\circ} \mathrm{W}$ and $48^{\circ} \mathrm{N} 21^{\circ} \mathrm{W}$, Deep-Sea Research, 31, 221-243, 1993.

Honjo, S., Dymond, J., Collier, R., and Manganini, S. J.: Export production of particles to the interior of the equatorial pacific ocean during the 1992 EqPac experiment, Deep-Sea Research, 42(2-3), 831-870, 1995.

Hopkinson, C. S. and Vallino, J. J.: Efficient export of carbon to the deep ocean through dissolved organic matter, Nature, 433, 142-145, 2005.

Hoppe, H-G.: Phosphatase activity in the sea, Hydrobiologia, 493, 187-200, 2003.

Jenkins, W. J.: Oxygen utilization rates in North Atlantic subtropical gyre and primary production in oligotrophic systems, Nature, 300, 246-248, 1982.

Kähler, P. and Bauerfeind, E.: Organic particles in a shallow sediment trap: Substantial loss to the dissolved phase, Limnology and Oceanography, 46(3), 719-723, 2001.

Kioerboe, T., Ploug, H., and Thygesen, U. H.: Fluid motion and solute distribution around sinking aggregates. 1. small-scale fluxes and heterogeneity of nutrients in the pelagic environment, Marine Ecology Progress Series, 211, 1-13, 2001.

Klaas, C. and Archer, D. E.: Association of sinking organic matter with various types of mineral ballast in the deep sea: implications for the rain ratio, Global Biogeochemical Cycles, 116, doi:10.1029/2001GB001765, 2002. 
Knauer, G. A., Karl, D. M., Martin, J. H., and Hunter, C. N.: In situ effects of selected preservatives on total carbon, nitrogen and metals collected in sediment traps, Journal of Marine Research, 42(2), 445-462, 1984.

Knauer, G. A. and Asper, V. (Eds.): Sediment trap technology and sampling, US GOFS Planning Report No. 10, 1989.

Knauer, G. A., Redalje, D. G., Harrison, W. G., and Karl, D. M.: New production at the VERTEX time-series site, Deep-Sea Research, 37, 1121-1134, 1990.

Kohly, A.: Diatom flux and species composition in the Greenland Sea and the Norwegian Sea in 1991-1992, Marine Geology, 145(3-4), 293-312, 1998.

Körtzinger, A., Schulz-Bull, D. E., Petrick, G., and Duinker, J. C.: Evidence for dissolution of fatty acids in sediment traps: impact on flux estimates, J. Geophys. Res., 99, 3407-3415, 1994.

Körtzinger, A., Koeve, W., Kähler, P., and Mintrop, L.: C:N ratios in the mixed layer during the productive season in the northeast Atlantic Ocean. Deep-Sea Research, 48(3), 661-688, 2001 a.

Körtzinger, A., Hedges, J. I., and Quay, P. D.: Redfield ratios revisited: Removing the biasing effect of anthropogenic $\mathrm{CO}_{2}$, Limnology and Oceanography, 46(4), 964-970, 2001b.

Lampitt, R. S., Raine, R. C. T., Billett, D. S. M., and Rice, A. L.: Material supply to the European continental slope: A budget based on benthic oxygen demand and organic supply, Deep-Sea Research, 42(11-12), 1865-1880, 1995.

Lee, C., and Cronin, C.: Particulate amino acids in the sea: Effects of primary productivity and biological decomposition. Journal of Marine Research, 42(4), 1075-1097, 1984.

Lee, C., Hedges, J. I., Wakeham, S. G., and Zhu, N.: Effectiveness of various treatments in retarding microbial activity in sediment trap material and their effects on the collection of swimmers, Limnology and Oceanography, 37(1), 117-130, 1992.

Liu, P.-C., Lee, K.-K., Tu, C.-C., and Chen, S.-N.: Purification and characterisation of a cysteine protease produced by pathogenic luminous Vibrio harveyi, Current Microbiology, 35, 32-39, 1997.

MacCready, P., and Quay, P.: Biological export flux in the southern ocean estimated from a climatological nitrate budget, Deep-Sea Research, 48, 4299-4322, 2001.

Martin, J. H., Knauer, G. A., Karl, D. M., and Broenkow, W. W.: VERTEX: Carbon cycling in the northeast pacific, Deep-Sea Research, 34, 267-285, 1987.

McCave, I. N.: Vertical flux of particles in the ocean, Deep-Sea Research, 22, 491-502, 1975.

Neuer, S., Ratmeyer, V., Davenport, R., Fischer, G. and Wefer, G.: Deep water particle flux in the Canary Island region: Seasonal trends in relation to long-term satellite derived pigment data and lateral sources, Deep-Sea Research, 44, 1451-1466, 1997.

Noji, T. T., Boersheim, K. Y., Rey, F., and Nortvedt, R.: Dissolved organic carbon associated with sinking particles can be crucial for estimates of vertical carbon flux, Sarsia, 84(2), 129-135, 1999.

Passow, U. : Transparent exopolymer particles (TEP) in aquatic environments, Progress in Oceanography, 55(3-4), 287-333, 2002.

Peterson, W. and Dam, H. G.: The influence of copepod "swimmers" on pigment fluxes in brine-filed and seawater-filled sediment traps, Limnology and Oceanography, 35, 448-455, 1990.

Pohl, C., Löffler, A., and Hennings, U.: A sediment trap flux study for trace metals under seasonal aspects in the stratified Baltic Sea
(Gotland Basin; $57^{\circ} 19.20^{\prime} \mathrm{N} ; 20^{\circ} 03.00^{\prime} \mathrm{E}$ ), Marine Chemistry, 84, 143-160, 2004.

Redfield, A. C., Ketcham, B. H., and Richards, F. A.: The influence of organisms on the composition of sea-water, in: The Sea, vol.2, edited by: Hill, M. N., Interscience, New York, 1963.

Reigstad, M., Heiskanen, A.-S., and Wassmann, P.: Seasonal and spatial variation of suspended and sedimented nutrients $(\mathrm{C}, \mathrm{N}, \mathrm{P})$ in the pelagic system of the Gulf of Riga, Journal of Marine Systems, 23, 211-232, 1999.

Rickert, D., Schlüter, M., and Wallmann, K.: Dissolution kinetics of biogenic silica from the water column to the sediments, Geochimica et Cosmochimica Acta, 66, 439-455, 2002.

Schaffer, G.: Biogeochemical cycling in the global ocean. 2. New Production, Redfield ratios and remineralization in the organic pump, J. Geophys. Res., 101 (C2), 3723-3745, 1996.

Schaffer, G., Bendtsen, J., and Ulloa, O.: Fractionation during remineralization of organic matter in the ocean, Deep-Sea Research, 46, 185-204, 1999.

Schlüter, M., Sauter, E. J., Schulz-Bull, D., Balzer, W., and Suess, E.: Organic carbon and biogenic silica cycle of surface sediments: a comparison of northern and southern latitudes of the Atlantic Oceans, in: North Atlantic: A changing environment, edited by: Schäfer, P., Ritzuau, W., Schlüter, M., and Thiede, J., Springer Heidelberg, 2000.

Schneider, B., Schlitzer, R., Fischer, G. and Nötig, E.-M.: Depthdependent elemental compositions of particulate organic matter (POM) in the ocean, Global Biogeochemical Cycles, 17, 1-16, 2003.

Scholten, J., Fietzke, J., Koeve, K., Van der Loeff MR, Mangini, A., Waniek, J., Antia, A. N., and Kuss, J.: Trapping efficiencies of deep sediment traps in the eastern north Atlantic and in the Arabian sea: Evidence from radionuclide studies, Deep-Sea Research, 48, 243-268, 2001

Shanks, A. L., and Trent, J. D.: Marine snow: Sinking rates and potential role in vertical flux, Deep-Sea Research, 27, 137-143, 1979.

Silver, M. W. and Alldredge, A. L.: Bathypelagic marine snow: deep-sea algal and detrital community, Journal of Marine Research, 39, 501-530, 1981

Simon, M., Grossart, H., Schweitzer, B. and Ploug, H.: Microbial ecology of organic aggregates in aquatic ecosystems, Aquatic Microbial Ecology, 28(2), 175-211, 2002.

Smith, D. C., Simon, M., Alldredge, A. L., and Azam, F.: Intense hydrolytic enzyme activity on marine aggregates and implications for rapid particle dissolution. Nature, 358, 139-141, 1992.

Smith, K. L., Kaufmann, R. S., Baldwin, R. J., and Carlucci, A. F.: Pelagic-benthic coupling in the abyssal eastern north pacific: An 8 -year time-series study of food supply and demand. Limnology and Oceanography, 46(3), 543-556, 2001.

Steinberg, D. K., Pilskaln, C. H., and Silver, M. W.: Contribution of zooplankton associated with detritus to sediment trap "swimmer" carbon in Monterey Bay, CA, Marine Ecology Progress Series, 164, 157-166, 1998.

Struck, U., Pollehne, F., Bauerfeind, E., and von Bodungen, B.: Sources for nitrogen for the vertical particle flux in the Gotland Sea (Baltic Proper)-results from sediment trap studies, Journal of Marine Systems, 45, 91-101, 2004. 
Takahashi, T., Broecker, W. S., and Langer, S.: Redfield ratios based on chemical data from isopycnal surfaces, J. Geophys. Res., 90(C4), 6907-6924, 1985.

Trull, T. W., Bray, S. G., Manganini, S. J., Honjo, S., and Francois, R.: Moored sediment trap measurements of carbon export in the subantarctic and polar frontal zones of the Southern Ocean, south of Australia, J. Geophys. Res., 106 (C12), 31 489-31 509, 2001.

Urban-Rich, J.: Release of dissolved organic carbon from copepod fecal pellets in the Greenland Sea. Journal of Experimental Marine Biology and Ecology, 232(1), 107-124, 1999. von Bodungen, B., Wunsch, M., and Fürderer, H.: Sampling and analysis of suspended particles in the North Atlantic, in: Marine Particles: Analysis and Characterisation, edited by: Hurt, D. W. and Spencer, D. W., Geophysical Monograph Series, American Geophysical Union, Washington, DC, 1991.

Yu, E., Francois, R., Bacon, M. P., and Fleer, A. P.: Fluxes of ${ }^{230} \mathrm{Th}$ and ${ }^{231} \mathrm{~Pa}$ to the deep sea: Implications for the interpretation of excess ${ }^{230} \mathrm{Th}$ and ${ }^{231} \mathrm{~Pa} /{ }^{230} \mathrm{Th}$ profiles in sediments, Earth and Planetary Science Letters, 191(3-4), 219-230, 2001. 